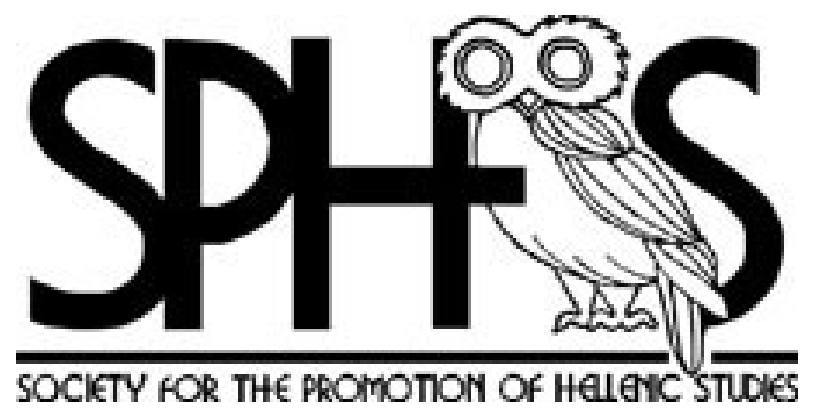

Politics in the Frogs of Aristophanes Author(s): J. T. Sheppard and A. W. Verrall

Source: The Journal of Hellenic Studies, Vol. 30 (1910), pp. 249-259

Published by: The Society for the Promotion of Hellenic Studies

Stable URL: http://www.jstor.org/stable/624304

Accessed: 16/11/2014 14:11

Your use of the JSTOR archive indicates your acceptance of the Terms \& Conditions of Use, available at

http://www.jstor.org/page/info/about/policies/terms.jsp

JSTOR is a not-for-profit service that helps scholars, researchers, and students discover, use, and build upon a wide range of content in a trusted digital archive. We use information technology and tools to increase productivity and facilitate new forms of scholarship. For more information about JSTOR, please contact support@jstor.org.

The Society for the Promotion of Hellenic Studies is collaborating with JSTOR to digitize, preserve and extend access to The Journal of Hellenic Studies. 


\section{POLITICS IN THE FROGS OF ARISTOPHANES.}

THE construction of the Frogs of Aristophanes is of a normal conventional type. From the appearance of Dionysus in his strange garb, appropriate to the patron of a heroic stage run mad on realism, to a Dionysus whose wine is new and his bottles old, the customary series of comic incidents develops the conventional situation. This introduction presents us with the antecedents, the background, and the grouping of a

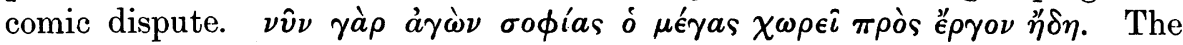
contest forms the main part of the drama; and, quite conventionally, it is separated from the introduction by a parabasis which offers a mixture of serious and comic advice. That the background is the nether world: that the disputants are so eminent a pair as Aeschylus and Euripides: that the judge is the god of all tragedy and comedy himself, and the chorus blessed spirits of the sanctified-all this illumines the old forms with a fresh and unrivalled originality. But the mechanical structure is simple and conventional, as has been said.

There are indeed certain inconsistencies of plot. In some of them the critics find evidence that in its present form the play is a revised edition, prepared for the second performance; others, we are told, are due to a change in the whole conception of the drama necessitated by the death of Euripides during its composition. These points are discussed by Mr. Rogers in his introduction, and in general $\mathbf{I}$ do not desire to contradict his conclusions. But there is one point, germane to my topic, which must be mentioned. When we are told that the conclusion of the poetic contest is ' a curious jumble'- -since the judgment goes in favour ' not necessarily of the better tragedian, but of the man who can give the state the wiser political counsel,'-we have, I think, a certain confusion of thought; and as I shall try to show in the sequel, we are led by too great insistence on mechanical detail to ignore a higher consistency of idea which is after all far more important. We are apt to forget that the test of a play is the effect not upon the analysing reader but upon an audience: I venture to think that in the politics of the Frogs we have a clue to a higher, more artistic unity than can be found by the analysis of the structure.

The literary contest is for the most part and in detail, quâ literary criticism, pure fun. If any serious-minded person still doubts it, we can happily refer him to Dr. Verrall's characteristic, and therefore delightful, 
treatment of the $\lambda \eta \kappa v i \theta \iota \nu$ episode in the New Quarterly Review ${ }^{1}$ - though some invincibly serious persons find in Dr. Verrall's 'had a bad cold and blew his little nose' not so much a defence of Euripides as an unscrupulous attack, a damaging attack, on Tennyson! Here, however, I need hardly labour the point that in spite of certain shrewd and pertinent thrusts, the criticism quâ literary criticism is for the most part ludicrous and meant to be ludicrous ; and that the seriousness, which is felt beneath the fun, rests on a contrast ultimately religious and moral. Even here there is an admirable lightness of touch. Euripides is not scourged: the exposure of sophistry is delicate, almost affectionate. It was not entirely the influence of Mr. Gilbert Murray, but also something in the spirit of the drama which left the audience on good terms with Euripides at the end of the Oxford performance. Aristophanes has succeeded in discrediting sophistry without making us hate the memory of the sophist. $\Pi \epsilon \iota \theta \omega$ is inadequate; but no Athenian can have felt less proud of Euripides at the end of the play than he was when he entered the theatre. Dionysus is in love with Euripides at the outset: he still delights in his cleverness at the end. 'Both are my friends, I can't decide between them.' Sophocles had put on mourning for Euripides: the people of Athens had surely mourned with him. Contrast the tone of this play with that of the Clouds: contrast the affectionate reference to Agathon with his treatment in other plays. The criticism of the modern point of view is, however, serious and sincere. The effect must have been that the audience sympathised with the spirit which is put into sharp contrast with it ; not, I think, that they cared less for the memory of the poet, whose works both the audience and Aristophanes appear to have known almost by heart.

But the contrast is sincere and serious. Euripides is the poet of reason and, if you will, of sophistry. Aeschylus is the poet of religion. It is important to notice the artistic skill with which this identification of Aeschylus with religion is made. It has not always been stated with sufficient clearness.

Aeschylus, the child of Eleusis, is the poet of the mysteries. That is one great reason why the $\mu v \sigma_{\tau} \iota \iota$ are here at all. It is to the Eleusinian goddess he prays,

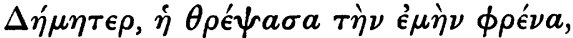

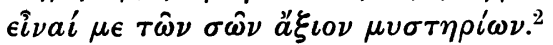

It is the epithet of the mystic deities that is conferred upon him. Compare :

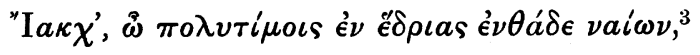

and

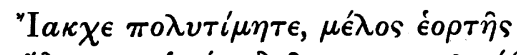

$\ddot{\eta} \delta \iota \sigma \tau o \nu \in \dot{v} \rho \omega \dot{\nu}, \delta \epsilon \hat{v} \rho \circ \sigma v \nu a \kappa o \lambda o v ́ \theta \epsilon \iota^{4}$

with the respectful appeal of Dionysus,

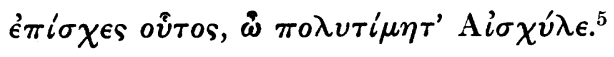
1 January, 1909.
3 Line 324 ; cf. also 337.
2 Line 886.
+ Line 398 .
5 Line 851. 
And this identification of the spirit of Aeschylus with the religion of the mysteries is driven home by a supremely artistic stroke in the mystic silence of Aeschylus when he first appears. ${ }^{6}$

Di. Aeschylus-why are you silent? You hear what he says.

Eur. He'll put on grand airs at first-the pompous trick he used to play in all his tragedies.

$D i$. Hush, my good fellow-no more irreverence!

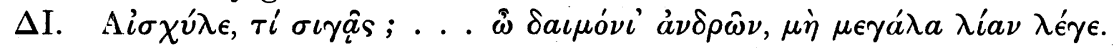

And again the same mystic silence is suggested by the self-satisfied but self-condemnatory attack of Euripides on the openings of his dramas :

He'd bring some single mourner on, seated and veiled, 'twould be

Achilles, say, or Niobe, the face you could not see, ${ }^{7}$

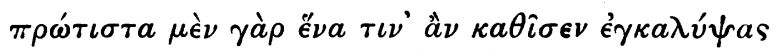

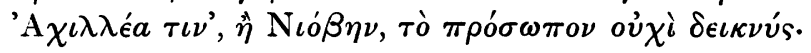

To which the comment of Dionysus is:

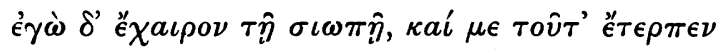

oủ $\chi \hat{\eta} \tau \tau o \nu \hat{\eta} \nu \hat{v} \nu$ oi $\lambda a \lambda o \hat{v} \nu \tau \epsilon \varsigma$.

The conflict, then, is religious and moral. But for this very reason it is inevitably political. The interest is indeed for us primarily literary. But statements, such as are frequently made to the effect that 'in the delicacy of the political situation' Aristophanes avoided politics, and chose 'a purely literary subject,' are misleading. ${ }^{8}$

They imply a distinction, a clear differentiation between the spheres of religion, morals, politics, and art which would have been incomprehensible to an Athenian even at the end of the fifth century. Aristophanes could not conceivably turn from Cleophon ${ }^{9}$ to Euripides with the sense that he was turning from the affairs of the state to the affairs of the individual: the affairs of the city are the affairs of the gods : the worship of the gods is the affair of the city. Religion for Aristophanes is an essential element of patriotism, and irreligion means political far more than personal obliquity. To say that the new culture has led the citizens away from the pious spirit and practice of Aeschylus is to say that the new culture has made the city less safe from her enemies. The people a few months before had executed their best generals, the victors of Arginusae, in a religious panic. Such a people could hardly find 'relief' from the anxieties of politics by turning to the consideration of the havoc wrought by irreligious poets in the sanctuary

${ }^{6}$ Line 832.

7 Line 911, Mr. Rogers' translation. Notice incidentally the reference to Achilles. We shall see later that it is not altogether without significance.

8 E.g. the late Sir Richard Jebb, essay on Sophocles in Essays and Addresses. Dr. Verrall in the article already mentioned.

$9 \mathrm{M}$. Croiset's remarks on the fact that Plato competed against Aristophanes with the 'Cleophon' in this year are notable in this connexion (Aristophane et les Partis à Athène, p. 244). 
of the tragic Dionysus himself. It is of course amazing, and it is to their eternal glory, that they could laugh with the poet even at their misfortunes. Throughout the play we have sinister hints, of what we know from other sources and from the sequel was the fact-treachery within the city-Thorycion, Adeimantus, who was to betray his countrymen at Aegospotami, oligarchs who cared more for themselves and their power than for Athens-demagogues, we must add, who though they were no traitors, yet for their own ascendancy's sake refused to hear of peace, the only hope for fresh prosperity -the allies gone-the money gone-the coinage debased-the food supplies in large measure cut off-many citizens suspect and disfranchised: some (and among them the greatest of all) in exile-no one in the audience, I suppose, who had not losi, a father or a brother or a friend by plague or battle or by the hemlock : many of them to be among the prisoners whom Lysander slaughtered after Aegospotami: none of them, except the traitors, who did not know that if Athens yielded he himself would probably die.

In such a case whither can one turn for relief unless to the goddesses who saved the city even though it was burnt to the ground, in the days of Salamis: the goddesses whom the conqueror had heard holding their own mystic celebrations when their worshippers had been driven out, the goddesses of Eleusis, vanquishers of the Persian? perhaps-but only if we put away our sophistries and quibbling impieties-willing to save us also from the present enemy, $\sigma \omega \tau \hat{\eta} \rho \epsilon \varsigma$ $\theta \epsilon o i$, par excellence $\sigma \omega \tau \hat{\eta} \rho \epsilon \varsigma^{10}$; for the individual the givers of a joyful life beyond; and to the city upon whom, as on the citizens, the clouds of death were hanging so low, the one great hope of possible $\sigma \omega \tau \eta \rho i a$ in this life here. It was by a happy insight that the designer of the Oxford programme chose for his symbol of the tragic contest the weighing of Persuasion against Death.

At this point we may recall the famous passage in the ancient life of Aristophanes: 'The praise and love which he won from his fellow-citizens was above all due to this - that he was zealous to show by his plays the freedom of the Athenian state: that it was led in chains of slavery by no tyrant, but was rather a democratia, whose people governed themselves in freedom. This was why he won praise, and was crowned with a wreath of the sacred olive-an honour which is regarded as equal to the golden crown-for his well-known words in the Frogs about the ä $\tau \iota \mu \circ$,

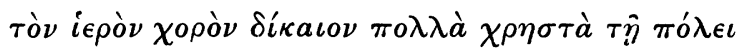 $\sigma v \mu \pi a \rho a . \iota \epsilon \hat{\imath} \nu . '$}

It is unnecessary to cite the words in the ancient argument in which, it will be remembered, we are told on the authority of Dicaearchus that it was the appeal of the parabasis to drop old enmities and suspicions and to enfranchise the disfranchised, which secured the play the honour of a second representation. It was for patriotic statesmanship that the poet received the wreath of Athene's olive.

10 It is profitalile to follow $\sigma \varphi^{\prime} \zeta \epsilon \iota \nu, \sigma \omega \tau \eta \dot{\eta} \rho, \sigma \omega \tau \eta \rho l a$ throughout the play 
If $I$ have succeeded in making myself clear, I think I shall be permitted to assume that the Athenians had not left behind their politics and their anxieties for the city when they came to witness the performance of this play. Let me now go further and say that the most important clue for the artistic appreciation of the play is to be found in the thoughts which must have been in Athenian minds when Xanthias and his donkey first appeared. The Athenians were thinking not merely of the gods who might yet save their city, not merely of the possibility of enlisting for the struggle all the discontented and suspected-they were thinking, we may be sure, of their exiles, and above all of their greatest exile, Alcibiades. Plutarch tells us how even after all was lost ' they looked upon their second quarrel with Alcibiades as the greatest of all their errors. They had cast him off without any offence of his : their anger had been grounded upon the ill conduct of his lieutenant, in losing a few ships, and their own conduct had been worse in depriving the commonwealth of the most excellent and valiant of all its generals, yet amidst their present misery there was one slight glimpse of hope that while Alcibiades survived Athens could not be utterly undone.' Can we doubt that in these earlier times, when Athens was straining every resource to preserve herself alive, the most urgent of all questions for the Athenians was the question of Alcibiades-can we be reconciled to him-would he be willing to come back: if he were willing could we so humble ourselves as to beg his aid-would the gods approve and save us; or would they make him a curse to us, as indeed he has sometimes been in the past? $\pi \circ \theta \epsilon \hat{\imath} \mu \epsilon^{\prime} \nu$,

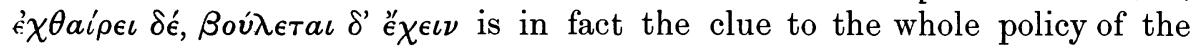
Frogs.

To resume: we have tried to show that a religious and moral discussion could not have been felt by the audience as essentially non-political-but rather would be felt to concern $\tau \dot{a} \mu \mu^{\prime} \gamma \iota \sigma \tau a \tau \hat{\eta} s \pi \dot{\lambda} \epsilon \epsilon \omega$. We know that the actual Athenian audience was above all things impressed by the political appeal of the $\pi a \rho a ́ \beta a \sigma \iota s$. And we have the word of Aristophanes as well as the general probability of the case to tell us that Alcibiades was in the minds of

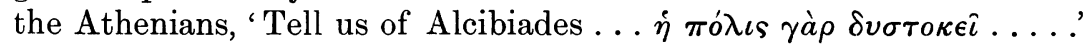

It is worth while to read again the noble lines in which the appeal is made, and to consider whether any man in the audience would have failed to think of Alcibiades when he heard (ostensibly of the disfranchised citizens) (I quote Mr. Murray), l. 697 :--

But remember these men also, your own kinsmen, sire and son, Who have ofttimes fought besides you, spilt their blood on many seas : Grant for that one fault the pardon which they crave you on their knees.

You whom nature made for wisdom, let your vengeance fall to sleep;

Greet as kinsmen and Athenians, burghers true to win and keep,

Whosoe'er will brave the storms and fight for Athens at your side!

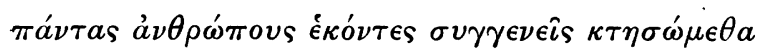

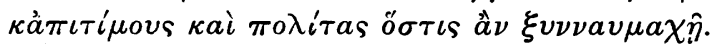

$\epsilon \grave{l} \delta \epsilon \tau a \hat{v} \tau^{\prime}$ ó $\gamma \kappa \omega \sigma o ́ \mu \epsilon \sigma \theta a \kappa a ̉ \pi o \sigma \epsilon \mu \nu v \nu o v ́ \mu \epsilon \theta a$,

H.S. VOL. XXX. 


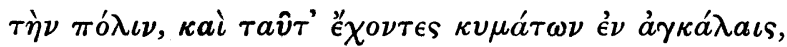

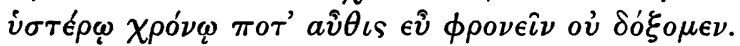

Let us, if you will, say that there is here no hint of exiles or of Alcibiades. In the Antepirrhema-when, as Mr. Rogers points out, the chorus is

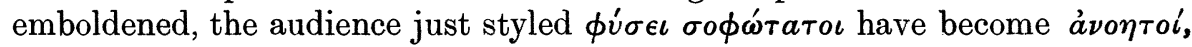
- the reference is clearer (727):-

Even so, our sterling townsmen, nobly born and nobly bred ${ }^{11}$

$\tau \hat{\omega} \nu \pi o \lambda \iota \tau \hat{\omega} \nu \delta^{\prime}$ ov̀s $\mu \epsilon \nu$ ' $\sigma \mu \epsilon \nu \epsilon \dot{v} \gamma \epsilon \nu \epsilon \hat{\imath} s \kappa a \grave{\imath} \sigma \omega ́ \phi \rho o \nu a s$

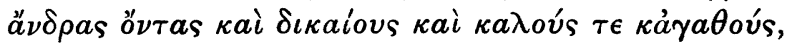

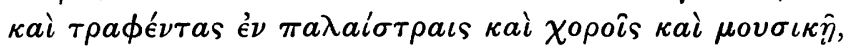
$\pi \rho \circ v \sigma \epsilon{ }^{\circ} \hat{v} \mu \epsilon \nu$,

and so on.

Even now, O race demented, there is time to change your ways;

Use once more what's worth the using. If we 'scape, the more the praise

That we fought our fight with wisdom; or if all is lost for good,

Let the tree on which they hang us be at least of decent wood.

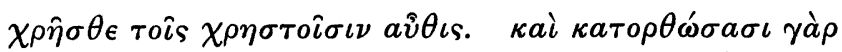

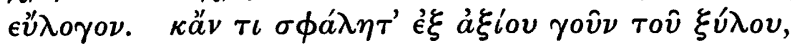

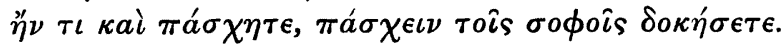

After that we are not surprised that the first words of the farcical scene

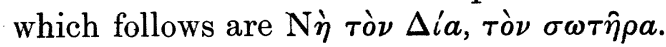

If you still doubt that Alcibiades was in the mind of the audience who applauded these lines, consider by whose mouth the parabasis is spoken. The speakers are the initiated. By songs and dances they have presented not, I think, a precise and realistic representation either of the greater or of the lesser mysteries-such a precise reproduction as is sometimes imagined would have been in accordance neither with piety nor with the recognized methods of Greek art-rather they have given suggestions which have filled the mind with thoughts of all the sacredness and solemnity of the most holy Eleusinia. ${ }^{12}$ If nothing had been said or thought of Alcibiades before, this spectacle must have suggested his name. The weightiest reason for the rejection of Alcibiades was his suspected impiety: he had been exiled first under the suspicion of a violation of those very mysteries : the weightiest reason for supposing that he now might save the state was that he had made his peace

11 Mr. Rogers.

12 Professor Tucker has argued convincingly, I think, against the pedantry which would make the chorus represent all the stages of the autumnal procession from Athens to Eleusis. But his argument is weaker when he attempts to show that the festival at Agrae alone is suggested. Spring-time and flowers are per- petual for the initiate in the other world. 'Where is this meadow?' asks Professor Tucker (Introduction, p. xxix) on 1. 325. The answer

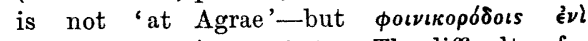
$\lambda \in \iota \mu \omega \dot{\nu} \epsilon \sigma \sigma \iota \pi \rho o \alpha ́ \sigma \tau \iota o \nu$ aủ $\tau \hat{\omega} \nu$. The difficulty of a theory of exact representation is shown by Professor Tucker's note on 1. 445. 
with the goddesses. Who could have seen this chorus without thinking of the day of his return (in 408) when the Eumolpidae and the herald had taken off the execrations which they had pronounced against him, and when Theodorus, the chief of the Eumolpidae said 'for his part he had never denounced any curse against him, if he had done no injury to the commonwealth'? Who can have failed to think of the greater day when as strategos he had 'taken the priests and the persons initiated and those who had the charge of initiating others, and coming down with his forces, led them on in great order and profound silence, exhibiting in the march a spectacle so august and venerable, that those who did not envy him declared he had performed not only the office of a general but of a high priest. ${ }^{13}$,

There were many who envied him : demagogues who were jealous of so great a rival: oligarchs who were the friends of Sparta: men like Cleophon on the one hand, and on the other Adeimantus, the traitor of Aegospotami, both of whom are attacked in the play. ${ }^{14}$

Such men had still the power and will to play upon the religious sentiment of Athenians and so keep Alcibiades under suspicion. That is why Aristophanes must go to work so carefully, suggesting throughout the play but only in the final scene announcing in so many words through the mouth of Aeschylus that in his opinion Alcibiades should be recalled. A sinner, he says, in effect-I admit it; but what great amends he made. And are we not all sinners too-with our love of sophistry and with the impiety it means. ${ }^{15}$ Turn from your sophistries, yes-but make friends with others who have also made their blunders. In his youth we know that Alcibiades was the friend of Socrates-but we have it on the testimony of Xenophon that his absorption in politics led to his estrangement from his master. It is probable that the suspicion which attached to all followers of that greatest of the sophists was the reason for the estrangement.

But it is possible to show in clearer detail how these considerations help us to understand the atmosphere of the play. The clues are death and sophistry: $\sigma \omega \tau \eta \rho i a$ and disaster due to impiety: the goddesses as $\sigma \omega \tau \hat{\eta} \rho \epsilon \varsigma-$ Alcibiades as $\sigma v^{\prime} \mu \mu a \chi \chi_{\text {s }}$ the sinner restored to the favour of the goddesses he has offended. Take first a small point: the words of Dionysus, 1. 71. I want a genuine poet :-

For some are gone, and those we have are bad,

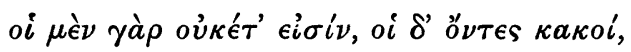

words in themselves suggestive of the desolation of the city at this time. But

13 Langhorne, Plutarch. Professor Tucker objects to the 'current theory that Athens was exulting over the exploit of Alcibiades,' and points out, with admirable humour, that 'people do not exult over a thing which they managed to do the year before last, but which they have been unable to do last year.' It is, of course, not a question of 'exulting over the exploit.'
Simply the representation of the Initiate at a time when Alcibiades is in the popular mind is enough.

14 See especially the closing scene, 1l. 15041513.

15 This consideration explains the comparative mildness of the attack on Euripides to which I have referred above. 
the scholiast tells us (he is quoted by Mr. Rogers) that the line is from the Oeneus of Euripides. Diomed addresses the deposed and exiled king :-

$$
\sigma \dot{v} \delta \text { ' } \hat{\omega} \delta \text { ' }
$$

to which the answer is :-

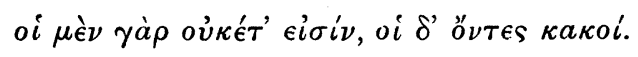

In the present case the situation is reversed. It is the city which $\hat{\omega} \delta \delta^{\prime}$ 'ै $\rho \mu$ os $\sigma v \mu \mu a ́ \chi \omega \nu$ àmó $\lambda \lambda v \tau a \iota$.

Is it not again Alcibiades whom the chorus seem to address, when in the contest, after their great appeal has been spoken, they turn to Aeschylus with

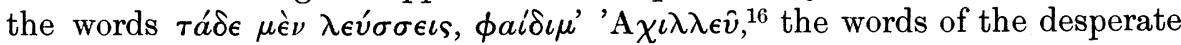
Myrmidons begging their lingering chieftain, offended like Alcibiades, essential to victory like Alcibiades, to lead them into battle :-

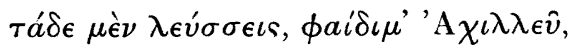

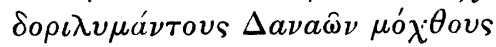

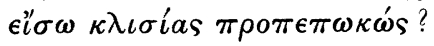

Pass on to the judgment of the prologues and notice how Aeschylus selects of all his plays the Choephoroe to quote-the play which, as I think the late Dr. Headlam was the first to point out, is full of allusions to the mysteries ${ }^{17}$ -and notice how each word tells ${ }^{18}$ :-

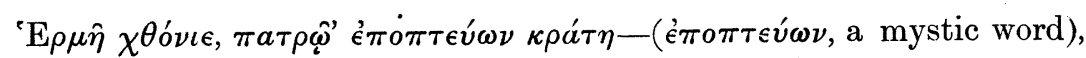

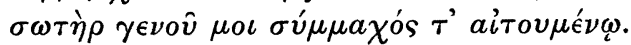

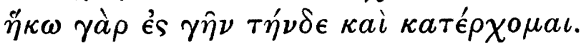

Here we have crammed into three lines, death, mysteries, $\sigma \omega \tau \eta \rho i a$, $\sigma u ́ \mu \mu a \chi o s$, and the return of an exile. There is some excellent fooling about the first line-then Aeschylus repeats again the second and the third. To which Euripides:-

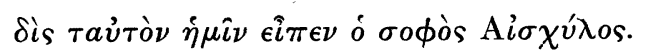

On literary grounds the defence of Aeschylus is neither necessary nor amusing :-

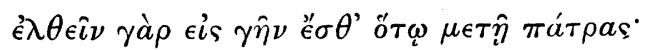

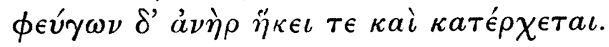

And Euripides retorts :-

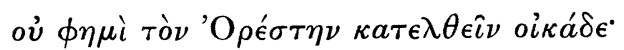

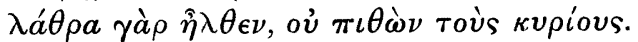

It is no longer for the Athenians to wait till Alcibiades sues for pardon - they must themselves take the initiative and pass a measure restoring his high honours and inviting him to return.

I have spoken of a reference to Achilles earlier in the play. If what I suggested seemed fanciful, let me now point out how the lines of Aeschylus which are produced by Euripides at 1264 begin with :-
16 Line 991.
$\rightarrow$ Class. Rev. 1903, p. 248.
18 Line 1126. 


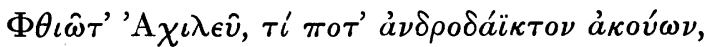

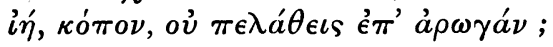

Lord of Phthia, Achilles, why, hearing the hero dividing, Hah ! smiting ! approachest thou not to the rescue?

And that four times the refrain recurs :-

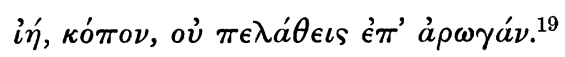

Turn next to the weighing of line against line. The first pair appears to me to be introduced merely as an excuse for the silly jest of Dionysusbut the second pair has long been felt to be full of meaning.

No shrine of persuasion save reasoned argument :-

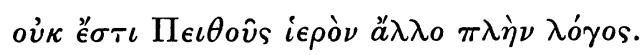

Euripides has placed persuasion in the scale, the weightiest of all his goods.

Death the only god who cares not for gifts,

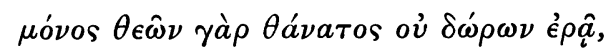

is the retort; and the sequel known to the audience is this:-

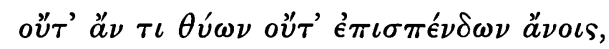

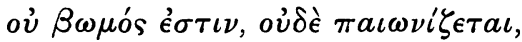

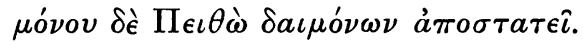

Sacrifice and libations avail not with death: death has no altar, and no paean: death is the one god whom persuasion troubles not.

Persuasion and argument and reason are specious; but death is the supreme fact of which reason has nothing to tell. Another reference to Achilles. And death again-death and war-is the reply to the 'ironclamped mace,' which Euripides next puts into the scale.

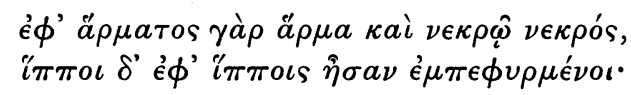

Chariot on chariot, dead on dead, horse upon horse, confusedly heaped.

At last comes the final contest :-

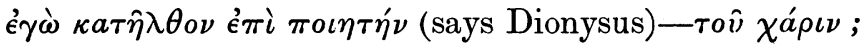

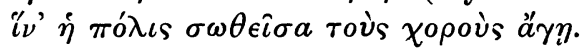

And the test is to be advice to the city-first about Alcibiades-and now for the first time he is mentioned by name.

\footnotetext{
19 Reference to Achilles in 1l. 912, 991, 1264, 1400 ; cf. Plutarch, Alcibiades, xxiii, 203 'E $\nu$

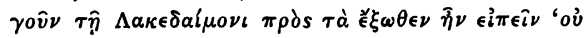

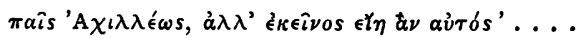
(of Alcibiades).
} 
a play, and a worthy symbol of the greatness of dying Athens-dying happily only, like the blessed initiate, to live again in the not less wonderful Athens of Plato.

J. T. SHEPPARD.

Dr. Verrall has kindly communicated the following note:-

Frogs 1167-8.

That the allusion here is political, I quite agree; and I think it possible to make a plausible guess at the facts in view. Suppose a vote to have been passed extending some grace to such exiles, or such exiles of some particular class, as had ' returned' ( $\kappa a \tau \hat{\eta} \lambda \theta o \nu$ or the like) by a specified date. Such a vote, unless very carefully worded, might easily raise important disputes of interpretation. Was the 'return' signified a return in fact or a return in law? Obviously many persons legally banished must have been resident by

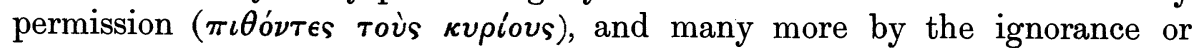
connivance of authority. Were these last within the meaning of the supposed grace? This might well be a very delicate and difficult question. Aristophanes, as Mr. Sheppard's paper shows, would certainly be for the more liberal interpretation. This I take him to indicate by putting the argument for the narrower (and probably sounder) construction into the mouth of Euripides and making Dionysus dismiss it as a quibble: 'A clever interpretation indeed! But what you mean, I do not understand.'

A. W. Verrall. 